\title{
PENGEMBANGAN BAHAN AJAR IPA SEKOLAH DASAR I BAGI MAHASISWA PGSD UNIVERSITAS LAMBUNG MANGKURAT
}

\author{
${ }^{1}$ Tika Puspita Widya Rini \\ ${ }^{1}$ Program Studi Pendidikan Guru Sekolah Dasar \\ FKIP, Universitas Lambung Mangkurat, Bnnjarmasin \\ e-mail: tika.rini@ulm.ac.id
}

\begin{abstract}
ABSTRAK
Penelitian ini bertujuan untuk Mengembangkan produk berupa bahan ajar IPA SD I di Program Studi Pendidikan Guru Sekolah Dasar Universitas Lambung Mangkurat. Adapun subjek dari penelitian ini adalah mahasiswa PGSD Universitas Lambung Mangkurat. Penelitian ini menggunakan pendekatan penelitian dan pengembangan. Sedangkan model pengembangan yang digunakan adalah model pengembangan Research \& Development (R\&D) dari Borg dan Gall. Sedangkan Teknik pengumpulan melalui observasi, wawancara, dan dokumentasi dengan analisa data yang digunakan model Miles and Huberman yaitu data reduction, data display, dan conclusion drawing/ verification. Hasil penelitian dari tim ahli uji validitas, dari uji ahli materi memperoleh 78,5\% dengan kategori valid, uji ahli media memperoleh $80 \%$ dengan kategori sangat valid, dan uji ahli bahasa sebesar $75 \%$ dengan kategori valid. Pada uji coba kelompok kecil diperoleh rata-rata respon sebesar 87,89 \% dengan kategori sangat baik, dan uji kelompok besar diperoleh rerata respon sebesar 88,56\% dengan kategori sangat baik. Hasil belajar mahasiswa mengalami peningkatan yang signifikan, pada uji coba kecil rerata hasil belajar siswa sebesar $86,7 \%$, dan pada uji coba kelompok besar memperoleh $90 \%$. Hal ini menunjukkan bahwa modul IPA Sekolah Dasar dinyatakan layak untuk dikembangkan dan dapat dipertanggungjawabkan secara keilmuan.
\end{abstract}

Kata kunci: Bahan Ajar, IPA Sekolah Dasar I

\section{ABSTRACT}

This study aims to develop products in the form of science teaching materials at SD I in the Primary School Teacher Education Study Program at Lambung Mangkurat University. The subjects of this study were PGSD Lambung Mangkurat University students. This study uses a research and development approach. While the development model used is the Research \& Development (R\&D) development model of Borg and Gall. While the technique of collecting through observation, interviews, and documentation with data analysis used the Miles and Huberman model, namely data reduction, data display, and conclusion drawing / verification. The results of the research from the team of experts validity test, from the material expert test obtained $78.5 \%$ with a valid category, the media expert test obtained $80 \%$ with a very valid category, and the linguist test by $75 \%$ with a valid category. In the small group trials an average response of $87.89 \%$ was obtained with the excellent category, and the large group test obtained an average response of $88.56 \%$ with the very good category. Student learning outcomes have increased significantly, in small trials the average 
student learning outcomes of $86.7 \%$, and in large group trials gained 90\%. This shows that the Elementary School Science module is declared feasible to be developed and can be scientifically justified.

Keywords: Teaching Materials, Elementary School Science I

\section{PENDAHULUAN}

Pembelajaran bertujuan untuk mengembangkan tiga ranah, yaitu kognitif, afektif, dan psikomotor dimana dalam implementasinya harus ada keterpaduan dari seluruh komponen baik komponen penyelenggaraan pendidikan yaitu guru/dosen maupun komponen kompetensi yang meliputi strategi pembelajaran, metode, alat peraga, dan tingkat perkembangan peserta didik (Sudjono, 2011:49). Salah satu pembelajaran yang mengedepankan keaktifan ketiga ranah tersebut adalah IPA. Hal ini dikarenakan pembelajaran IPA identik dengan pengembangan rasa ingin tahu melalui proses penemuan, proses penyaluran ide-ide kreatif. Sehingga, pendidikan IPA diarahkan untuk dapat menstimulus peserta didik melalui berbagai pertanyaan yang mengkonstruksi kognitif serta karakter agar dapat membantu memperoleh pemahaman yang lebih mendalam terhadap suatu konsep.

Sejalan dengan hal tersebut dalam kurikulum Perguruan Tinggi yang mengacu kepada KKNI memfasilitasi para peserta didik yaitu mahasiswa melalui suatu mata perkuliahan yaitu IPA Sekolah Dasar I dengan bertujuan agar para calon guru yaitu mahasiswa PGSD memiliki pengetahuan yang mumpuni mengenai IPA khusunya "Biologi". Sehingga, untuk memenuhi kompetensi tersebut diperlukan suatu bahan ajar yang dapat digunakan oleh mahasiswa dalam menggali pengetahuan secara merata dan mendalam mengenai materi "Biologi". Tetapi pada kenyataannya berdasarkan pada pengamatan, masih belum atau sedikitnya bahan ajar yang terkait langsung dengan mata perkuliahan IPA Sekolah Dasar I untuk mahasiswa PGSD yang digunakan sebagai acuan untuk mengembangkan sains. Adanya bahan ajar ini diharapkan mahasiswa PGSD dapat menambah sumber belajar terkait dengan mata perkuliahan IPA Sekolah Dasar I. Bahan ajar berfungsi sebagai pedoman bagi mahasiswa dalam mempelajari sesuatu. Dengan adanya buku ajar mahasiswa dapat merancang, metode, permainan, dan media sians yang menyenangkan. Selain mahasiswa, bahan ajar ini juga dapat digunakan oleh para guru dan juga orang tua yang ingin mengenalkan konsep sains sederhana untuk anaknya di rumah.

Selain itu, penelitian relevan yang dilakukan oleh Buyung (2018) bahwasanya dengan mengembangkan suatu produk bahan ajar terhadap mata perkuliahan menyebabkan 
kemampan mahasiswa memahami materi tersebut meningkat. Penelitian yang serupa dilakukan oleh Arafat (2018) bahwa dengan mengembangkan bahan ajar dapat efektif meningkatkan hasil belajar dan kemampuan kognitif siswa. Mengacu pada uraian diatas, maka peneliti merasa perlu dan tertarik untuk mengembangkan produk berupa bahan ajar IPA Sekolah Dasar I untuk memenuhi kebutuhan mahasiswa PGSD akan referensi dalam pemahaman materi perkuliahan serta untuk mengembangkan pembelajaran sains PGSD.

\section{PENGEMBANGAN BAHAN AJAR}

Menurut Ranjit dikutip oleh Ibrahim (2016:282) menyebutkan sepuluh tahapan dalam mengembangkan bahan pembelajaran yaitu: 1) identifikasi kebutuhan dan permasalahan, 2) analisis masalah, 3)merumuskan dan menetapkan tujuan, 4) menyeleksi topik, 5) menyeleksi bentuk, 6) menyeleksi konten, 7) editing, 8) testing (pengujian), 9) revisi. Lebih lanjut Andang, dkk (2017: 148-149) mengungkapkan langkah-langkah dalam pengembangan bahan ajar yaitu:

1. Analisis

Bahan ajar yang dikembangkan sesuai dengan kebutuhan siswa dalam melaksanakan pembelajaran. Sehingga pembelajaran menjadi efektif dan bermakna.

2. Perancangan

Perancangan bahan ajar diambil dari berbagai seumber untuk dijadikan sebagai referensi belajar. perumusan tujuan pembelajaran yang jelas, menentukan topik dan materi pembelajaran yang tepat.

3. Pengembangan

Setelah perumusan tujuan pembelajaran, langkah selanjutnya guru menentukan materi pembelajaran. Yang perlu diperhatikan dalam penentuan materi ini adalah ruang lingkup materi, keluasaan, dan kedalaman, serta kesesuaian materi dengan tujuan pembelajaran yang akan dicapai.

4. Evaluasi

Evaluasi bahan ajar dilakukan dengan melakukan uji coba. Bahan ajar ajar yang dibuat ditelaag oleh ahli untuk uji kevalidan kereliabelan.

5. Revisi

Tahapan revisi dilakukan sebagai bentuk perbaikan jika terdapat kekurangan dalam pengembangan bahan ajar. Seperti: menghilangkan bagian-bagian yang tidak penting, memperluan penjelasan, penambahan latihan dan contoh. 
Salah satu bentuk bahan ajar yang sering digunakan guru dengan menggunakan buku. Lebih lanjut Majid (2017: 175) menyebutkan buku adalah sejumlah lembaran kertas yang berisi pengetahuan hasil analisis kurikulum yang dijilid dan diberi kulit. Jadi, buku kegiatan anak adalah lembaran kertas yang ditulis berisikan aktivitas-aktivitas yang menunjang pengembangan aspek perkembangan anak dalam pembelajaran.

Suprihatiningrum (2017: 305-306) mengungkapkan langkah-langkah penentuan materi dalam pembelajaran yaitu:

1. Analis is standar komptensi dan kompetensi dasar

Penelaahan standar kompetensi dan kompetensi dasar ini untuk menentukan tujuan pembelajaran yang akan dicapai. Oleh karena itu tujuan pembelajaran bersifat nyata dan dapat diukur.

2. Identifikasi jenis-jenis materi pembelajaran

Tujuan pembelajaran yang telah dibuat berdasarkan pada aspek sikap, pengetahuan, dan keterampilan. Langkah selanjutnya menyesuaikan materi ke dalam ranah-ranah tersebut. Materi pembelajaran yang sesuai dengan ranah afektif ditentukan berdasarkan perilaku aspek sikap, nilai-nilai, dan moral. Materi pembelajaran yang sesuai dengan ranah pengetahuan berdasarkan pada perilaku kognitif. Sedangkan materi pembelajaran yang sesuai dengan ranah keterampilan yang menekankan pada aspek motorik kasar dan halus.

3. Strategi urutan penyampaian

Penyampaian materi dilakukan secara urut dengan langkah-langkah sebagai berikut:

a. Bahan yang disampaikan benar dan tidak salah konsep

b. Bahan disampaikan dengan lancar

c. Bahan disampaikan secara sistematis

d. Bahan disampaikan dengan bahasa yang komunikatif, baik dan benar

\section{Materi IPA Sekolah Dasar I}

Mata Kuliah IPA SD 1 ini mempelajari Biologi dan ciri-ciri kehidupan; sel sebagai dasar kehidupan dan pembelahan sel; keanekaragaman makhluk hidup dan klasifikasi makhluk hidup; tumbuhan biji terbuka dan tumbuhan biji tertutup; keanekaragaman hewan; ekosistem dan saling ketergantungan serta pola interaksi organisme; transportasi dan pernafasan pada tumbuhan serta gerak pada tumbuhan; makanan dan sistem pencernaan pada manusia; sistem pernafasan pada manusia; vertebrata dan hewan invertebrata; sistem pengeluaran pada vertebrata, invertebrata, dan manusia; adaptasi makhluk hidup; perkembangbiakan; dan pencemaran pada manusia. 


\section{METODE}

Penelitian ini menggunakan pendekatan penelitian dan pengembangan "research and development". Sedangkan model pengembangan yang digunakan dalam penelitian ini adalah model pengembangan desain Borg \& Gall dalam Putra (2012:119) yang terdiri dari 10 langkah yakni sebagai berikut: (1) Research and information collecting (mengumpulkan informasi dan melakukan penelitian awal; (2) Planning (perencanaan); (3) Developing preliminary form of product (mengembangkan produk awal); (4) Preliminary field testing (uji coba awal); (5) Main product revision (melakukan revisi untuk produk utama; (6) Main field testing (melakukan uji coba laapangan); (7) Operational product revision (melakukan revisi untuk menyusun produk operasional; (8) Operational field testing (melakukan uji coba penyempurnaan produk yang telah disempurnakan); (9) Final product revision (melakukan revisi produk final); and (10) Dessimination and implementation (menyampaikan laporan penelitian).

Subjek penelitian ini adalah: (a) validasi ahli yang terdiri dari 1 ahli materi, 1 ahli media dan 1 ahli bahasa; dan (b) mahasiswa Semester 1 yang berjumlah 58 orang. Sedangkan teknik pengumpulan data melalui observasi, wawancara, dan dokumentasi dengan analisa data yang digunakan model Miles and Huberman yaitu data reduction, data display, dan conclusion drawing/verification.

\section{HASIL}

Produk yang dikembangkan dalam penelitian ini berupa modul IPA Sekolah Dasar I. Materi yang dikembangkan dalam modul ini adalah Mata Kuliah IPA SD 1 ini mempelajari Ilmu Sains khususnya Biologi. Pemilihan materi-materi ini didasarkan pada materi mata perkuliahan IPA Sekolah Dasar I yang dapat dikembangkan dalam pembelajaran siswa sekolah dasar. Modul ini juga memuat berbagai contoh dan kata kunci dari setiap konsep IPA khususnya Biologi, sehingga dapat digunakan oleh guru dan Mahasiswa calon guru sekolah dasar dalam memahami materi perkuliahan IPA Sekolah Dasar I. Hal ini akan berdampak pada implementasi pembelajaran yang lebih bervariasi dan konsep biologi siswa dapat dikembangkan secara optimal.

Setelah produk berupa media pembelajaran modul IPA Sekolah Dasar I dikembangkan, maka tahapan berikutnya adalah evaluasi para ahli yang bertujuan untuk memberikan penilaian kritik, dan saran tentang media tersebut. Dalam uji kelayakan media ini terdapat dua tahap yaitu tahapan uji kelayakan secara teoritik dan uji kelayakan secara empiris. Uji kelayakan secara teoritik melibatkan para ahli (expert evalution) yang ahli 
dibidangnya, sedangkan uji kelayakan secara empiris melibatkan peserta didik sebaga pengguna (uji skala kecil dan uji skala besar). Pada setiap tahap dilakukan revisi atas media pembelajaran buku matematika anak usia dini yang dievaluasi berdasarkan masukan dari responden. Adapun hasil uji kelayakan dari para ahli adalah sebagai berikut:

Tabel 1. Uji Kelayakan dari Ahli Media

\begin{tabular}{|c|c|c|}
\hline No & Indikator & Keterangan \\
\hline 1 & Desain media sesuai dengan materi IPA (Biologi) & Relevan/Baik \\
\hline 2 & $\begin{array}{l}\text { Desain media sesuai dengan konsep pelestarian } \\
\text { lingkungan }\end{array}$ & Relevan/Baik \\
\hline 3 & Desain media menarik dilihat & Relevan/Baik \\
\hline 4 & Desain media menyajikan contoh dan gambar & Relevan/Baik \\
\hline 5 & Pemilihan warna dalam media & Relevan/Baik \\
\hline 6 & Pemilihan media yang unik & Relevan/Baik \\
\hline 7 & $\begin{array}{l}\text { Pengemasan materi dalam bahan ajar sesuai dengan } \\
\text { pendekatan keilmuan yang bersangkutan } \\
\text { (pendekatan saintifik) dan menarik }\end{array}$ & Relevan/Baik \\
\hline 8 & $\begin{array}{l}\text { Tampilan media menarik dan mudah } \\
\text { dibawa/dipindahkan }\end{array}$ & Relevan/Baik \\
\hline 9 & Diberi Judul/keterangan media & Relevan/Baik \\
\hline 10 & $\begin{array}{l}\text { Penyajian media mampu mengembangkan minat } \\
\text { belajar peserta didik }\end{array}$ & Relevan/Baik \\
\hline
\end{tabular}

Tabel 2. Uji Kelayakan dari Ahli Materi

\begin{tabular}{|c|c|c|}
\hline No & Indikator & Keterangan \\
\hline 1 & $\begin{array}{l}\text { Materi relevan dengan kompetensi yang harus dikuasai } \\
\text { peserta didik. }\end{array}$ & Relevan/Baik \\
\hline 2 & $\begin{array}{l}\text { Kelengkapan materi sesuai dengan tingkat perkembangan } \\
\text { siswa. }\end{array}$ & Relevan/Baik \\
\hline 3 & Materi cukup memenuhi tuntutan kurikulum yang berlaku & Relevan/Baik \\
\hline 4 & $\begin{array}{l}\text { Ilustrasi materi sesuai dengan tingkat perkembangan } \\
\text { peserta didik. }\end{array}$ & Cukup Relevan \\
\hline 5 & Ilustrasi media yang cukup fungsional & Cukup Relevan \\
\hline 6 & Materi yang disajikan sesuai dengan kebenaran keilmuan. & Relevan/Baik \\
\hline 7 & $\begin{array}{l}\text { Materi yang disajikan sesuai dengan perkembangan yang } \\
\text { mutakhir }\end{array}$ & Relevan/Baik \\
\hline 8 & Materi yang disajikan sesuai dengan kehidupan sehari-hari. & Relevan/Baik \\
\hline 9 & $\begin{array}{l}\text { Pengemasan materi dalam bahan ajar sesuai dengan } \\
\text { pendekatan keilmuan yang bersangkutan (pendekatan } \\
\text { saintifik) }\end{array}$ & Relevan/Baik \\
\hline 10 & Menyajikan kompetensi yang harus dikuasai peserta didik. & Sangat Baik \\
\hline 11 & Kesesuaian konsep terhadap materi yang disajikan. & Sangat Baik \\
\hline 12 & Mendorong rasa ingin tahu & Relevan/Baik \\
\hline 13 & Mendorong terjadinya interaksi antar peserta didik & Relevan/Baik \\
\hline
\end{tabular}




\begin{tabular}{llll}
\hline 14 & $\begin{array}{l}\text { Mendorong peserta didik membangun pengetahuannya } \\
\text { sendiri }\end{array}$ & Relevan/Baik \\
& Mendorong peserta didik belajar secara berkelompok & Cukup Relevan \\
\hline
\end{tabular}

Tabel 3. Uji Kelayakan dari Ahli Bahasa

\begin{tabular}{llc}
\hline No & \multicolumn{1}{c}{ Indikator } & Keterangan \\
\hline $\mathbf{1}$ & Ketepatan struktur kalimat & Relevan/Baik \\
$\mathbf{2}$ & Keefektifan kalimat & Cukup Relevan \\
$\mathbf{3}$ & Kebakuan istilah & Relevan/Baik \\
$\mathbf{4}$ & Pemahaman terhadap pesan & Relevan/Baik \\
$\mathbf{5}$ & Kemampuan memotivasi peserta didik & Cukup Relevan \\
$\mathbf{6}$ & Kesesuaian terhadap perkembangan intelektual peserta didik & Relevan/Baik \\
$\mathbf{7}$ & Kesesuaian dengan tingkat emosional peserta didik & Relevan/Baik \\
$\mathbf{8}$ & Ketepatan tata bahasa & Relevan/Baik \\
$\mathbf{9}$ & Ketepatan ejaan & Relevan/Baik \\
\hline
\end{tabular}

Data uji kelayakan dari para ahli menyatakan bahwasannya penilaian berdasarakan rerata ataupun persentase pada kelayakan produk dalam penelitian ini adalah :(1) kelayakan media sebesar $80 \%$ dalam kategori valid; (2) uji dari ahli materi sebesar $78 \%$ dalam kategori valid; dan (3) uji dari ahli bahasa sebesar 75,5\% dalam kategori valid. Sehingga produk ini layak digunakan untuk kepentingan pendidikan.

Uji yang dilakukan setelah uji kelayakan dari para ahli adalah uji kelayakan empiris yang dibagi menjadi dua kelompok, yakni kelompok kecil dan kelompok besar. Uji kelayakan empiris ini dilakukan untuk melihat keefektifan pengembangan modul pembelajaran ipa dengan melihat respon dari mahasiswa dan hasil belajar mahasiswa dalam pembelajaran IPA SD 1. Adapun data yang diperoleh adalah sebagai berikut:

Tabel 4. Respon Mahasiswa Terhadap Modul Pembelajaran IPA SD I

\begin{tabular}{llcc}
\hline No & \multicolumn{1}{c}{ Indikator } & \multicolumn{2}{c}{ Respon Mahasiswa (\%) } \\
\cline { 3 - 4 } & & Setuju & Tidak Setuju \\
$\mathbf{1}$ & Kelayakan Penyajian & 85,7 & 14,3 \\
$\mathbf{2}$ & Kelayakan Kegrafikan & 80 & 20 \\
$\mathbf{3}$ & Kelayakan Modul & 100 & - \\
\hline
\end{tabular}

Tabel 5. Penilaian Hasil Belajar Mahasiswa pada Uji Coba Skala Kecil dan Uji Coba Skala Besar 


\begin{tabular}{|c|c|c|c|c|c|}
\hline \multirow[t]{2}{*}{ No } & \multirow[t]{2}{*}{ Nilai } & \multicolumn{2}{|c|}{ Uji Coba Kecil } & \multicolumn{2}{|c|}{ Uji Coba Besar } \\
\hline & & $f$ & $\%$ & $F$ & $\%$ \\
\hline 1 & $91-100$ & - & - & - & - \\
\hline 2 & $81-90$ & 3 & $33,3 \%$, & 15 & $30 \%$ \\
\hline 3 & $71-80$ & 5 & $53,4 \%$ & 30 & $60 \%$ \\
\hline 4 & $<70$ & 7 & $13,3 \%$ & 5 & $10 \%$ \\
\hline \multicolumn{2}{|c|}{ Jumlah Total } & 15 & 100 & 50 & 100 \\
\hline \multicolumn{2}{|c|}{ Rerata > KKM } & & 43,35 & & 45 \\
\hline
\end{tabular}

\section{PEMBAHASAN}

Hasil akhir dari penelitian ini adalah sebuah produk berupa modul pembelajaran IPA Sekolah Dasar I untuk meningkatkan minat belajar dan hasil belajar mahasiswa PGSD dalam mempelajari konsep Biologi. Konsep dari pembuatan produk ini adalah berupa materi biologi yang dipilih secara random sesuai dengan materi pembelajaran IPA yang terdapat pada siswa sekolah dasar. Berdasarkan dari data yang telah dianalisis sebelumnya menunjukkan bahwa keberhasilan mahasiswa dalam memahami materi IPA yang sesuai dengan siswa sekolah dasar dapat dilihat dari tes kemampuan mahasiswa. Hal ini dapat diartikan bahwa media yang dikembangkan sudah efektif untuk digunakan di mata kuliah IPA Sekolah Dasar I di program studi PGSD. Penelitian dan pengembangan modul pembelajaran IPA Sekolah Dasar I tidaklah sempurna yang memiliki keterbatasan yaitu penelitian ini hanya dilakukan di program studi PGSD FKIP ULM. Berikut ini akan dijelaskan beberapa kelebihan dan kekurangan modul pembelajaran IPA Sekolah Dasar I yaitu sebagai berikut:

\section{Kelebihan Produk}

Beberapa kelebihan yang dimiliki oleh produk hasil pengembangan ini adalah sebagai berikut:

a) Produk yang dihasilkan memiliki cover yang menarik, sesuai dengan konsep biologi, dan memiliki kontras warna yang berbeda-beda sehingga mahasiswa yang membacanya tidak merasa monoton dan bosan.

b) Produk yang dihasilkan menampilkan layout yang berbeda dari modul-modul biasanya, sehingga pengguna merasa termotivasi untuk memahami materi lebih lanjut. 
c) Produk yang dihasilkan dilengkapi dengan kompetensi yang harus dicapai oleh mahasiswa sehingga dapat mengukur kemampuan mahasiswa dalam memahami konsep IPA khususnya konsep Biologi.

d) Produk yang dihasilkan memaparkan materi secara runtut dan lengkap sehingga pengguna lebih mudah memahami materi dengan baik.

\section{Kekurangan Produk}

Selain kelebihan, produk ini juga memiliki beberapa kekurangan. Akan tetapi, kekurangan tersebut telah diperbaiki. Berikut adalah beberapa kekurangan produk modul pembelajaran IPA Sekolah Dasar I yaitu:

a) Setiap materi hendaknya diberikan contoh berupa gambar-gambar yang jelas, akan tetapi kekurang ini telah direvisi dengan menambahkan gambar-gambar disetiap materi atau contoh dari materi untuk memudahkan pengguna memahami materi secara utuh.

b) Terdapat dibeberapa bagian, jenis dan ukuran font yang tidak konsisten, layout yang berbeda, dan kalimat yang tidak jelas dan sudah direvisi sehingga jenis dan ukuran font pada materi bisa terbaca dengan jelas, layout yang dibuat disusun secara sistematis, dan revisi terhadap beberapa kalimat.

c) Sedikitnya gambar yang ditampilkan dalam produk, akan tetapi kekurangan ini telah direvisi dengan menambahkan beberapa gambar yang sesuai dengan materi untuk memudahkan pengguna dalam memahami materi tersebut.

\section{KESIMPULAN}

Berdasarkan hasil penelitian dapat disimpulkan bahwa :

1. Hasil yang diperoleh pada saat uji validasi yang terdiri dari 3 orang yaitu uji ahli materi, uji ahli media, dan uji ahli bahasa adalah sebagai berikut:

a. Uji ahli materi, diperoleh nilai persentase sebesar 78\% dengan kategori "valid", namun perlu adanya beberapa revisi dan dapat dilanjutkan untuk uji coba kecil.

b. Uji ahli media, diperoleh nilai persentase sebesar $80 \%$ dengan kategori "sangat valid", tidak terdapat kekurangan yang berarti namun perlu ada pengembangan yang terdapat pada modul IPA Sekolah Dasar I dan dapat dilanjutkan untuk uji coba kecil. 
c. Uji ahli bahasa, diperoleh nilai persentasesebesar $75,5 \%$ dengan kategori "valid", namun perlu adanya beberapa revisi pada modul dari segi kebahasaan dan dapat dilanjutkan untuk uji coba kecil.

2. Pada uji coba kecil didapatkan hasil respon mahasiswa mengenai modul IPA Sekolah Dasar dan juga hasil belajar mahasiswa dalam memahami materi IPA khususnya Biologi sebagai berikut:

a. Respon mahasiswa mengenai modul IPA Sekolah Dasar dari segi :1) kelayakan penyajian mendapatkan rerata 95\% dengan respon "ya/setuju" dan 5\% dengan respon "tidak setuju"; 2) kelayakan kegrafikan diperolah $80 \%$ dengan respon "ya/setuju"dan $20 \%$ dengan respon "tidak setuju"; dan 3) kelayakan modul diperoleh $88,67 \%$ dengan respon "ya/setuju" dan $11,33 \%$ denan respon "tidak setuju".

b. Hasil belajar mahasiswa pada saat pretest dan posttest dengan rerata nilai yang sesuai KKM yaitu 71 adalah) pretest mahasiswa memperoleh rerata sebesar $26,65 \%$ dan posttest memperoleh rerata sebesar $43,35 \%$. sehingga kenaikan hasil belajar mahasiswa mengalami peningkatan sebesar $16,7 \%$.

3. Pada uji coba kecil didapatkan hasil respon mahasiswa mengenai modul IPA Sekolah Dasar dan juga hasil belajar mahasiswa dalam memahami materi IPA khususnya Biologi sebagai berikut:

a. Respon mahasiswa mengenai modul IPA Sekolah Dasar dari segi :1) kelayakan penyajian mendapatkan rerata $85,7 \%$ dengan respon "ya/setuju" dan $14,3 \%$ dengan respon "tidak setuju"; 2) kelayakan kegrafikan diperolah $80 \%$ dengan respon "ya/setuju"dan $20 \%$ dengan respon "tidak setuju”; dan 3) kelayakan modul diperoleh $100 \%$ dengan respon "ya/setuju".

b. Hasil belajar mahasiswa pada saat pretest dan posttest dengan rerata nilai yang sesuai KKM yaitu 71 adalah) pretest mahasiswa memperoleh rerata sebesar 29\% dan posttest memperoleh rerata sebesar $45 \%$. sehingga kenaikan hasil belajar mahasiswa mengalami peningkatan sebesar $16 \%$.

4. Hasil evaluasi formatif dari dari beberapa validasi ahli/pakar menyimpulkan bahwa produk pengembangan bahan ajar IPA Sekolah Dasar I telah dilakukan sesuai dengan metode, prosedur, prinsip, dan berpedoman pada model pengembangan, penelitian pendahuluan, pengembangan produk dan evaluasi formatif. Tim ahli/pakar merekomendasikan bahwa model yang dikembangkan layak digunakan. Dan di lanjutkan dengan, small group, dan field trial dan hasil semua uji coba 
mendapat hasil yang baik sehingga bahan ajar IPA Sekolah Dasar I layak digunakan.

\section{DAFTAR PUSTAKA}

Andang, dkk. 2017. Strategi Pembelajaran. Yogyakarta: CV Budi Utama.

Arafat, Maulana. 2018. Pengembangan Bahan ajar komik untuk meningkatkan minat baca ppkn siswa min ramba padang kabupaten tapanuli selatan. Jurnal Tarbiyah 2(25)152173.

Arikunto, Suharsimi. 2015. Dasar-Dasar Evaluasi Pendidikan. Jakarta: Bumi Aksara.

Buyung. 2018. Pengembangan bahan ajar pada mata kuliah belajar dan pembelajaran di fakultas keguruan dan ilmu pendidikan universitas batanghari jambi. Jurnal ilmiah Universitas batanghari jambi 3(18) 509-517.

Depdiknas. 2008. Panduan Pengembangan Bahan Ajar. Jakarta: Direktorat Pembinaan Sekolah Menengah Atas.

Kemendiknas. (2008). Penulisan Modul. Jakarta: Dikdasmen.

Majid, Abdul. 2017. Perencanaan Pembelajaran (Mengembangkan Standar Kompetensi Guru). Bandung: Remaja Rosdakarya

Mayer, Richard. E \& Alexander, Patricia. A. (2011). Handbook of Research on Learning and Instruction. Now York: Routledge.

Prastowo, A. 2015. Panduan Kreatif Membuat : BahanAjar Inovatif. Jogjakarta: DIVA Press.Sari, Arini Kumala dan Syafei, An Fauzia Rozani. 2013.Using Scratch to Create Multimedia-Based Material in Teaching English. Journal of English Language Teaching.Vol. 1. No.2.Hal: 39-42. UNP: Padang.

Putra, Nusa. Research \& Development Penelitian dan Pengembangan: Suatu Pengantar. 2012. Jakarta: Rajawali Pers.

Sudjono. 2011. Pengantar Evaluasi Pendidikan. Jakarta: Rajawali Pers.

Sugiyono. 2008. Metode Penelitian Kuantitatif Kualitatif dan R\&D. Bandung: Alfabeta.

Suprihatiningrum, Jamil. 2017. Strategi Pembelajaran (Teori \& Aplikasi). Jogjakarta: ArRuzz Media

Tim Pustlitjaknov. 2008. Metode Penelitian Pengembangan. Jakarta: Depdiknas 